\title{
Lower-rim ferrocenyl substituted calixarenes : new electrochemical sensors for anions
}

\author{
Philip A. Gale, ${ }^{a}$ Zheng Chen, ${ }^{a}$ Michael G. B. Drew, ${ }^{b}$ and Jennifer A. Heath ${ }^{a}$ \\ and Paul D. Beer ${ }^{* *}$ \\ "Inorganic Chemistry Laboratory, University of Oxford, South Parks Road, Oxford, OXI 3QR, U.K. \\ bepartment of Chemistry, University of Reading, Whiteknights, Reading RG2 6AD, U.K.
}

(Received 23 July 1997; accepted 16 September 1997)

\begin{abstract}
New ferrocene substituted calix[4 and 5]arenes have been prepared and the crystal structure of a lower-rim substituted bis ferrocene calix [4]arene (7) has been elucidated. The respective ferrocene/ferrocenium redox-couples of compounds 6 (a calix [4]arene tetra ferrocene amide) and 8 (a calix[5]arene pentaferrocene amide) are shown to be significantly cathodically perturbed in the presence of anions by up to $160 \mathrm{mV}$ in the presence of dihydrogen phosphate. (C) 1998 Elsevier Science Ltd. All rights reserved
\end{abstract}

Keywords: sensors; ferrocene; calixarene ; anion binding ; amide ; electrochemistry.

Anions are ubiquitous in biological systems [1]. Many proteins contain inorganic phosphate or sulfate anions coordinated via hydrogen bonds from water, amino-acid residues or amide bonds [2]. Additionally excess phosphate pollutants in the environment cause eutrophication of rivers and inland waterways [3], whereas nitrate pollutants and their metabolites are believed to be carcinogenic [4]. There is therefore great interest in the synthesis of receptor species containing hydrogen bond donor arrays [5,6], Lewis acid centres [7] or positive charges [8,9] as sequestering agents or sensors for anions. Early work by ourselves [10-13] and others $[14,15]$ established that amide $\mathrm{N}-\mathrm{H}$ groups in acyclic synthetic receptor molecules can coordinate anions. As part of this work we demonstrated that the calix[4]arene 1, which contains a lower-rim ferrocene amide bridge is capable of electrochemically detecting the presence of anions via perturbations of the ferrocene/ferrocenium redox couple [16].

As a further extension to this work we decided to synthesise a series of calixarenes containing multiple amidoferrocenyl residues at the lower rim and study these systems as potential amperometric sensors for anions.

* Author to whom correspondence should be addressed.

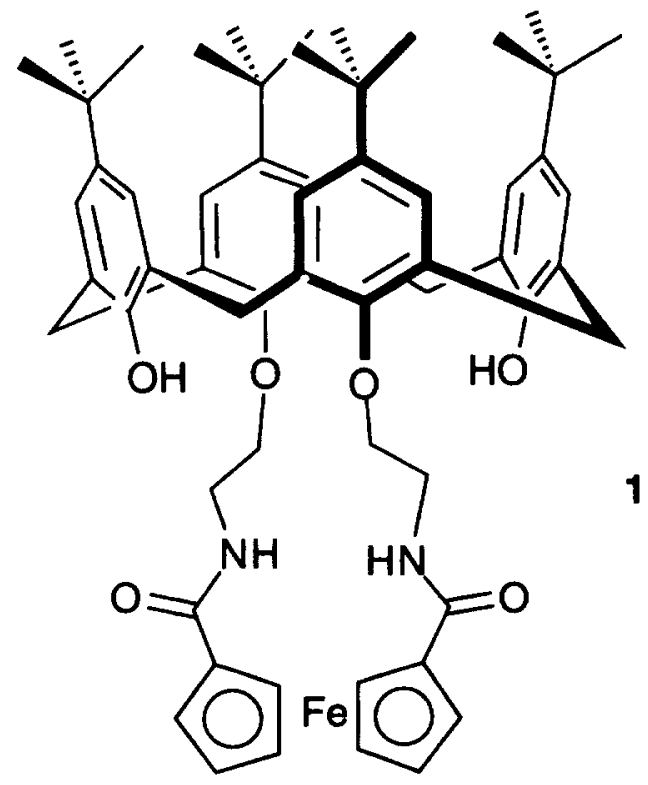

RESULTS AND DISCUSSION

Syntheses

p-tert-Butycalix[4]arene tetra (acid chloride) 2, $p$ tert-butycalix[4]arene bis (acid chloride) 3, p-tert- 
butycalix [5]arene penta (acid chloride) 4 [17,18] and ferrocenemethylamine 5 [19] were synthesised via literature procedures. An analogous synthetic procedure was employed in the preparation of each of the new calixarene-ferrocene conjugate compounds. Typically, the calixarene acid chloride was dissolved in dry dichloromethane, a $25 \%$ excess of ferrocenemethylamine 5 and triethylamine added, and the reaction mixture stirred under nitrogen overnight, in darkness. After washing with water, drying over magnesium sulfate and removal of solvent in vacuo, a pale brown solid was generally produced. This was purified by column chromatography (silica support) using dichloromethane/methanol as eluent affording the $p$-tert-butycalix[4]arene tetra amidoferrocene 6 in $21 \%$ yield, the p-tert-butylcalix[4]arene bis amidoferrocene 7 in $29 \%$ yield and the p-tert-butycalix [4] arene bis amidoferrocene 8 in 16\% yield (Scheme 1). The moderate yields of these reactions may be due to the incomplete reaction of the calixarene acid chlorides with ferrocenemethylamine (due to steric interactions), leading to incomplete substitution of ferrocene at the lower rim of the calixarene.

\section{Crystallography}

Diffraction quality single crystals of 7 were grown from a dichloromethane/methanol solvent mixture. The structure confirms that 7 adopts the cone conformation in the solid state (Fig. 1) with two ferrocene groups appended at the lower rim. The calixarene has usual $\mathrm{C}_{2}$ distortion with the angles between the plane of the four methylene groups and the four phenyl rings being $44.2,66.0,52.9$ and $70.6^{\circ}$, respectively. As can be seen in the figure, there is a dichloromethane molecule encapsulated within the cavity. Crystal data is given in Table 1 .

\section{Anion coordination studies: NMR titrations}

${ }^{1} \mathrm{H}$ NMR titrations were carried out in dichloromethane- $d_{2}$ solutions of compounds 6,7 and 8 . In a typical titration, $5 \times 10^{-6} \mathrm{~mol}$ of receptor was dissolved in $0.5 \mathrm{ml}$ dichloromethane- $d_{2}$ and equivalents of the anion added as $n-\mathrm{Bu}_{4} \mathrm{~N}^{+} \mathrm{X}^{-}\left(\mathrm{X}^{-}=\mathrm{Cl}^{-}\right.$, $\mathrm{HSO}_{4}^{-}$or $\left.\mathrm{H}_{2} \mathrm{PO}_{4}^{-}\right)$in dichloromethane- $d_{2}(0.1 \mathrm{~mol}$ $\mathrm{dm}^{-3}$ ) solution. The shifts of resonances of protons involved in anion coordination were then recorded and plotted as a function of the amount of anion added. Disappointingly, in the case of 7 , no significant shifts, i.e. greater than $0.01 \mathrm{ppm}$, were observed indicating that there is little interaction between this molecule and the anionic species. Partial substitution reduces the number of amide hydrogen bond donor sites at the lower rim of 7 compared to 6 and 8 , and this may be the cause for the poor anion coordination ability of this ligand. Another possibility is that in solution, the phenolic $\mathrm{OH}$ groups are hydrogen bonded to the amide functionalities via either
$\mathrm{OH} \cdots \mathrm{O}=\mathrm{C}$ or $\mathrm{HO} \cdots \mathrm{H}-\mathrm{N}$ hydrogen bonds so blocking the potential coordinating sites. This is reflected in the chemical shift of the amide resonance in the ${ }^{1} \mathrm{H}$ NMR spectrum of 7 which occurs at 8.74 ppm (i.e. it is deshielded relative to the amide protons of 6 and 8 which resonate at 7.57 and $7.42 \mathrm{ppm}$, respectively). The tetra- and penta- substituted derivatives, however, display significant downfield shifts of the amide $\mathrm{NH}$ proton (approximately $0.1 \mathrm{ppm}$ ) in the presence of anions (Figs 2 and 3). This indicates that the amide NH protons are coordinating to the added anions. Titrations with compounds 6 or 8 with chloride anions produced titration curves which could be fitted to a $1: 1$ calixarene/anion stoichiometric model. Stability constants were determined with the EQNMR computer program [20] and are shown in Table 2. Compound 6 forms a more stable complex with chloride $\left(55 \mathrm{M}^{-1}\right)$ than does compound $8\left(15 \mathrm{M}^{-1}\right)$. This may be due to a spacial fit effect, with chloride coordinating to the amide moieties of 6 more efficiently than to those of the calix[5]arene 8. An adequate fit could not be obtained for the titrations of 6 and 8 against hydrogen sulfate and dihydrogen phosphate to models consistent with $1: 1$ receptor/anion stoichiometries. This may be due to the formation of complexes of other stoichiometries, or aggregation of the anions in the relatively non-polar dichloromethane solvent. Unfortunately, precipitation problems were encountered during the titration studies upon addition of higher concentrations of anions. This precluded the limiting chemical shifts of the anion complexes in these experiments from being found.

\section{Anion coordination studies : electrochemistry}

The electrochemical properties of 6,7 and 8 were investigated using cyclic voltammetry [21] in a dichloromethane/acetonitrile $(35: 65 \mathrm{v} / \mathrm{v})$ solvent mixture, with $(n-\mathrm{Bu})_{4} \mathrm{NBF}_{4}$ as the supporting electrolyte. The working electrode used was a $5 \mathrm{~mm}$ glassy carbon disk and the counter electrode consisted of a platinum mesh. $\mathrm{A} \mathrm{Ag} / \mathrm{Ag}^{+}$electrode was used as reference (+ $330 \mathrm{mV}$ vs S.C.E.). Argon gas saturated with dichloromethane was continually bubbled through the cell to de-oxygenate the solution. It must be noted that in all cases electrochemical experimentation proved difficult with many precipitation and solubility problems encountered, as well as frequent adsorption of the oxidised species onto the electrode in the presence of anions. Each of the ligands exhibited a single quasireversible oxidation wave in the region 0.12 to $0.20 \mathrm{~V}$ (vs Ag/ $\mathrm{Ag}^{+}$) (Table 2, Fig. 4) suggesting the ferrocene moieties are behaving independently of one another and are therefore being oxidised at the same potential.

Thin layer coulometry was used to confirm that 6 , 7 , and 8 are undergoing four, two and five electron oxidations, respectively. In each case, the number of electrons transferred to the compound in question was found to be approximately equal to the number of ferrocene subunits present. 

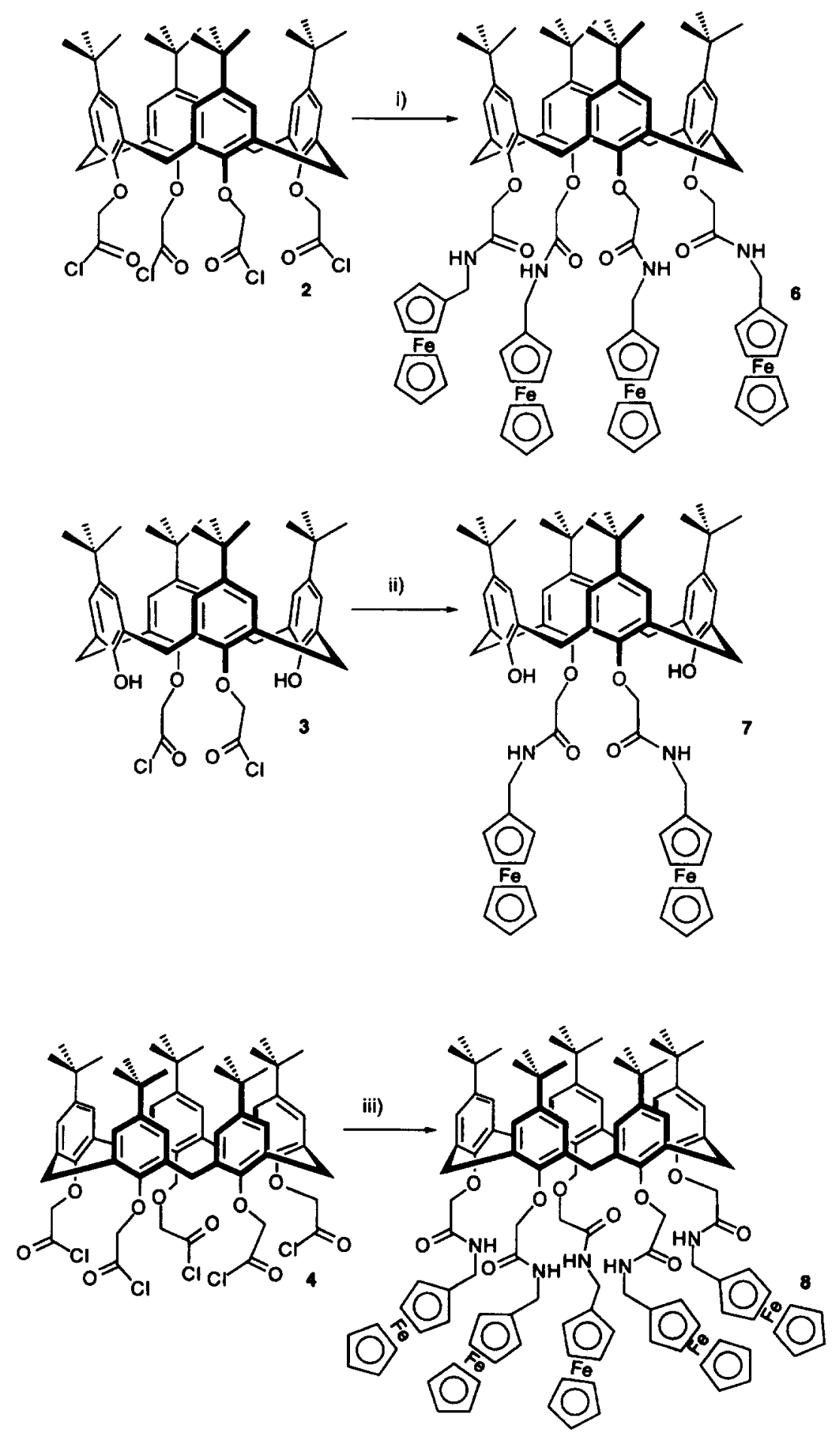

i) $5.0 \mathrm{FCCH}_{2} \mathrm{NH}_{2}, 5.0 \mathrm{~Eb} / \mathrm{N} / \mathrm{CH}_{2} \mathrm{Cl}$

ii) $2.5 \mathrm{FCCH}_{2} \mathrm{NH}_{2}, 2.5 \mathrm{Et} \mathrm{N} / \mathrm{CH}_{2} \mathrm{Cl}_{2}$

iii) 6.0 $\mathrm{FCCH}_{2} \mathrm{NH}_{2}, 6.0 \mathrm{Et} 3 \mathrm{~N} / \mathrm{CH}_{2} \mathrm{Cl}_{2}$

Scheme 1. 


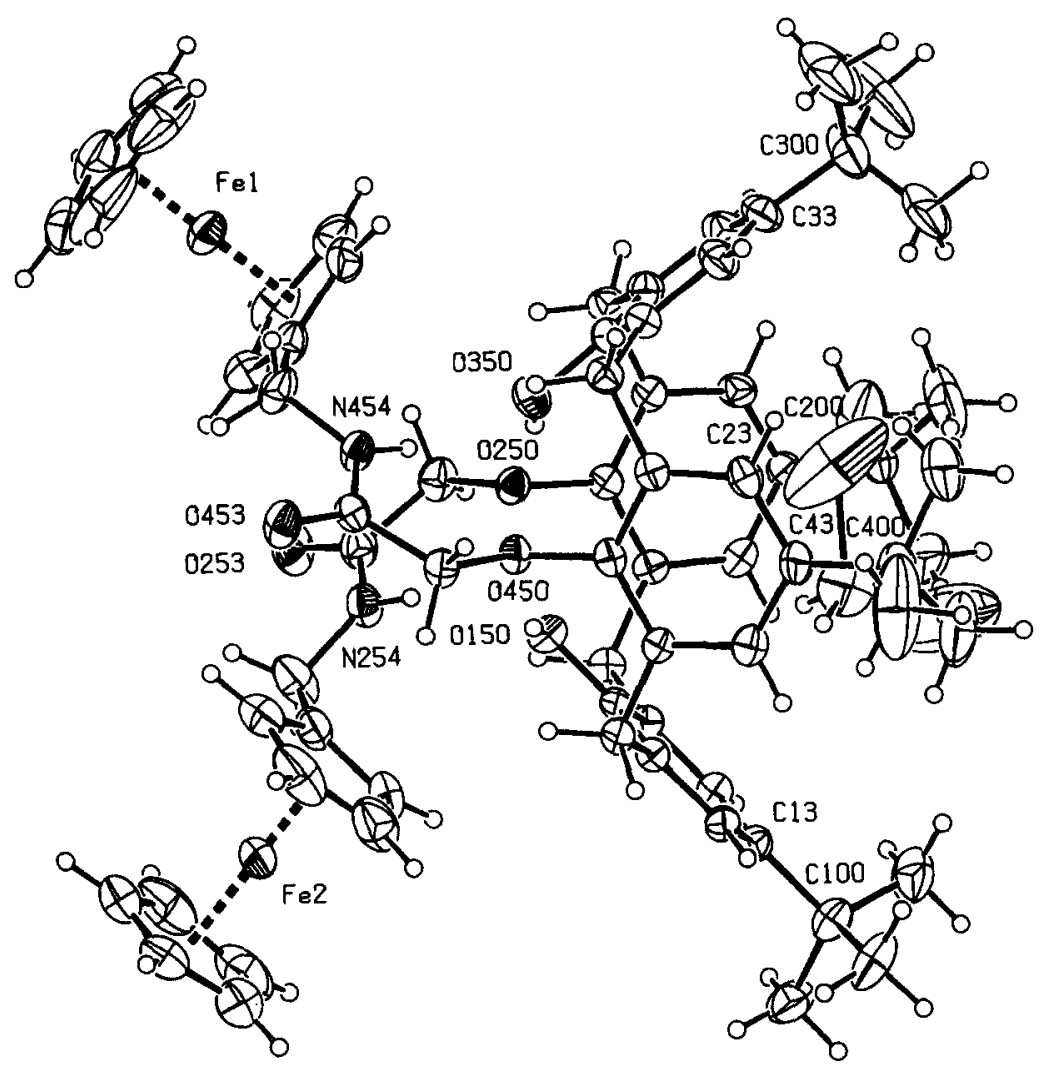

Fig. 1. The structure of 7 , with thermal ellipsoids drawn at the $30 \%$ probability level. Hydrogen atoms are included as small circles of arbitrary small radius. Intramolecular hydrogen bonds (not shown) are formed between the amide nitrogen atoms and the phenolic $\mathrm{OH}$ groups $\{\mathrm{N}(254) \cdots \mathrm{O}(150) 2.98 \AA, \mathrm{N}(454) \cdots \mathrm{O}(350) 2.94 \AA\}$.

Cyclic voltammograms were also recorded after progressive addition of stoichiometric equivalents of anionic guests as $0.1 \mathrm{M}$ solutions of $\left(n-\mathrm{Bu}_{4} \mathrm{~N}\right) \mathrm{H}_{2} \mathrm{PO}_{4}$, $\left(n-\mathrm{Bu}_{4} \mathrm{~N}\right) \mathrm{HSO}_{4}$ and $\left(n-\mathrm{Bu}_{4} \mathrm{~N}\right) \mathrm{Cl}$ in $\mathrm{CH}_{2} \mathrm{Cl}_{2} / \mathrm{CH}_{3} \mathrm{CN}$ $(35: 65 \mathrm{v} / \mathrm{v})$ to the electrochemical solutions of 6,7 and $8\left(1 \times 10^{-3} \mathrm{M}\right)$ in $\mathrm{CH}_{2} \mathrm{Cl}_{2} / \mathrm{CH}_{3} \mathrm{CN}(35: 65 \mathrm{v} / \mathrm{v})$, and the results are summarised in Table 3 .

The addition of anions to electrochemical solutions of 6 and 8 produced cathodic shifts of the ferrocene/ferrocenium redox couple with the relative magnitudes following the order $\mathrm{H}_{2} \mathrm{PO}_{4}^{-}>\mathrm{Cl}^{-}$ $>\mathrm{HSO}_{4}^{-}$. The most significant results were observed with compounds 6 and 8 with $\mathrm{H}_{2} \mathrm{PO}_{4}^{-}$anions, Fig. 5. Similar results were observed with compound 1 [16].

The addition of dihydrogen phosphate anions causes a $160 \mathrm{mV}$ cathodic shift in the ferrocene/ferrocenium redox couple. This large cathodic shift indicates a strong stabilisation of the oxidised forms of 6 and 8 , in the presence of dihydrogen phosphate. This may be due to dihydrogen phosphate coordination to the amide moieties of the calixarene, a consequence of suitable cavity size as defined by the pendant ferrocene amide groups. This places the anion in close proximity to the ferrocene/ferrocenium moiet- ies, so perturbing the redox potential of these groups. No analogous result was observed with 7 (in agreement with the prior ${ }^{1} \mathrm{H}$ NMR titration studies).

\section{Conclusions}

In conclusion the redox-active ferroceneamide derivatised calix [4,5]arenes $(6)$ and $(8)$ have been shown to bind and electrochemically detect anions. The stability constants of 6 and 8 with chloride anions have been determined and found to be $55 \mathrm{M}^{-1}$ and $15 \mathrm{M}^{-1}$, respectively. Compounds 6 and 8 electrochemically recognise $\mathrm{Cl}^{-}, \mathrm{HSO}_{4}^{-}$and $\mathrm{H}_{2} \mathrm{PO}_{4}^{-}$anions with $\mathrm{H}_{2} \mathrm{PO}_{4}^{-}$producing the largest shift of the ferrocene/ferrocenium redox couple $(160 \mathrm{mV})$.

\section{EXPERIMENTAL}

\section{General methods}

All elemental analyses were carried out by the Inorganic Chemistry Laboratory Microanalysis Service. NMR spectra were recorded on a Bruker AM300 NMR spectrometer. Infrared spectra were recorded 
Table 1. Crystal data and structure refinement for 7

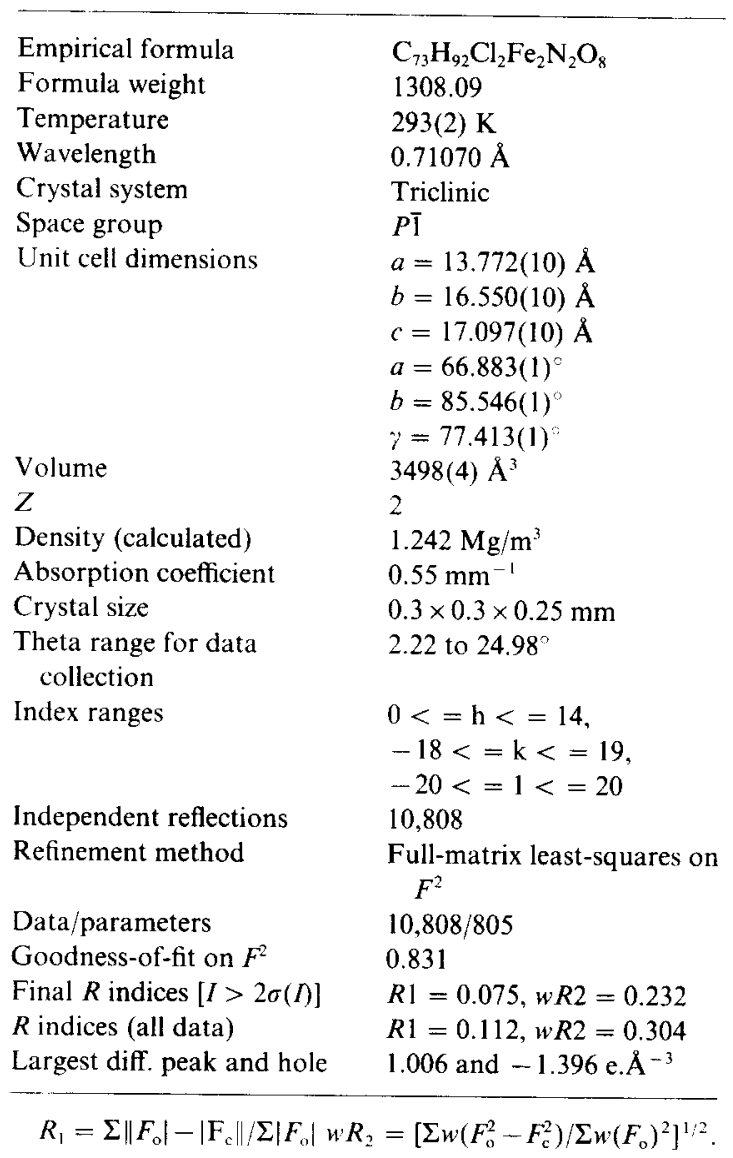

on a Mattson "Polaris" and Perkin Elmer "1710" Infrared Fourier Transform Spectrometers. Electrochemical experiments were conducted on a Princeton Applied Research Potentiostat/Galvanostat Model 273. Fast atom bombardment (FAB) mass spectra were carried out at the University of Wales, Swansea by the SERC/EPSRC Mass Spectrometry Service. Melting points were recorded in open capillaries on a Gallenkamp melting point apparatus and are uncorrected.

Synthesis of p-tert-butycalix[4]arenetetraferroceneamide (6)

Ferrocenemethylamine $(0.61 \mathrm{~g}, 2.84 \mathrm{mmol})$ was dissolved in dry $\mathrm{CH}_{2} \mathrm{Cl}_{2}(30 \mathrm{ml})$ and added to $p$-tertbutycalix[4]arene bis (acid chloride) (n $56 \mathrm{mmol}$ ). $\mathrm{Et}_{3} \mathrm{~N}(0.29 \mathrm{~g}, 2.87 \mathrm{mmol})$ was then added anc the reaction mixture stirred under nitrogen overnight. After washing with water $(4 \times 25 \mathrm{ml})$, the organic layer was dried over magnesium sulfate. The solvent was then removed under reduced pressure to give a pale brown solid which was purified by column chromatography on silica gel, gradient eluting with $\mathrm{CH}_{2} \mathrm{Cl}_{2} / \mathrm{MeOH}$ (gradient elution: concentration of
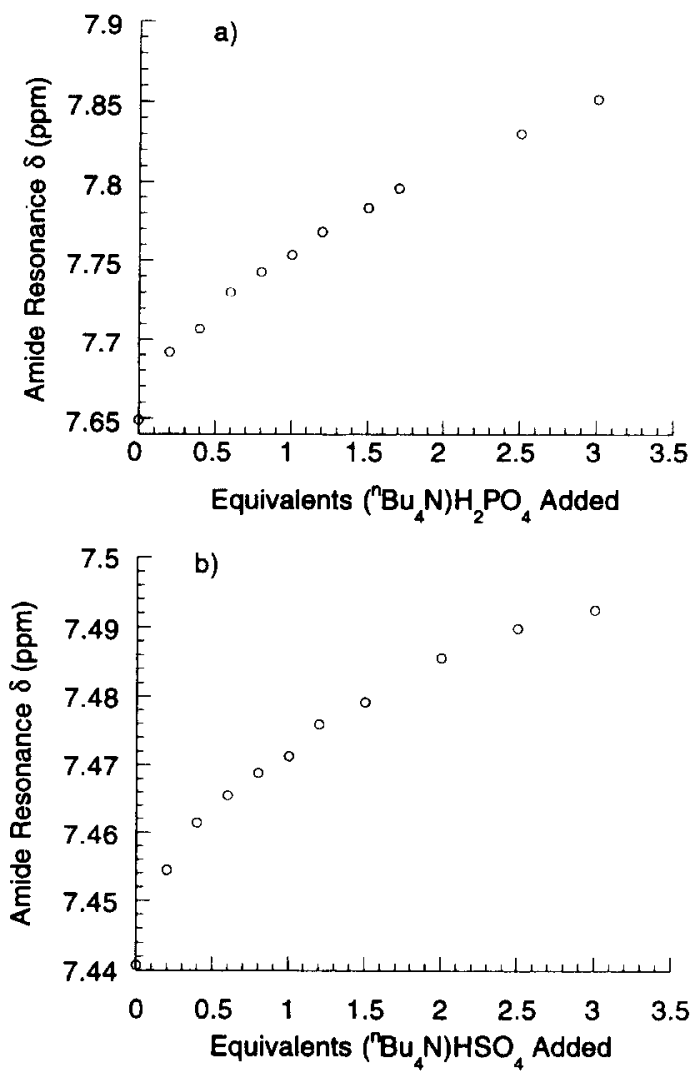

Fig. 2. NMR titrations $\left(\mathrm{CD}_{2} \mathrm{Cl}_{2}\right)$ (a) 6 with $\left(n-\mathrm{Bu}_{4} \mathrm{~N}\right) \mathrm{H}_{2} \mathrm{PO}_{4}$ and (b) 8 with $n-\mathrm{Bu}_{4} \mathrm{NHSO}_{4}$.

methanol from $0 \%$ to $5 \%$ ). The product was collected, reduced in vacuo and then precipitated as a yellow powder from a dichloromethane/methanol solvent mixture as a yellow powder $(0.2 \mathrm{~g}, 21 \%)$. ${ }^{1} \mathrm{H}$ NMR $\left(\mathrm{CDCl}_{3}, 300 \mathrm{MHz}\right) \delta: 1.05\left(\mathrm{~s}, 36 \mathrm{H}, \mathrm{C}\left(\mathrm{CH}_{3}\right)_{3}\right), 3.12$ $\left(\mathrm{d},{ }^{2} \mathrm{~J}=12.5 \mathrm{~Hz}, 4 \mathrm{H}, \mathrm{ArCH}_{2} \mathrm{Ar}: \mathrm{H}_{\mathrm{eq}}\right), 4.11(\mathrm{~m}, 8 \mathrm{H}$, $\mathrm{FcH}), 4.16(\mathrm{~s}, 20 \mathrm{H}, \mathrm{FcH}), 4.25(\mathrm{~m}, 8 \mathrm{H}, \mathrm{FcH}), 4.32$ $\left(\mathrm{d}, 8 \mathrm{H},-\mathrm{NHCH}_{2} \mathrm{Fc}\right)$ and $\left(\mathrm{d}, 4 \mathrm{H}, \mathrm{ArCH}_{2} \mathrm{Ar}: \mathrm{H}_{\mathrm{ax}}\right)$ coincident, $4.36\left(\mathrm{~s}, 8 \mathrm{H}, \mathrm{OCH}_{2}\right), 5.31\left(\mathrm{CH}_{2} \mathrm{Cl}_{2}\right), 6.72$ $(\mathrm{s}, 8 \mathrm{H}, \mathrm{ArH}), 7.57(\mathrm{t}, 4 \mathrm{H}, \mathrm{NH}),{ }^{13} \mathrm{C}$ NMR/DEPT $\left(\mathrm{CDCl}_{3}, 75.42 \mathrm{MHz}\right) \delta: 31.33\left(\left(\mathrm{CH}_{3}\right)_{3} \mathrm{C}\right), 31.49$ $\left(\mathrm{ArCH}_{2} \mathrm{Ar}\right), \quad 33.66 \quad\left(\mathrm{C}_{\left.\left(\mathrm{CH}_{3}\right)_{3}\right),}, \quad 38.70\right.$ $\left(-\mathrm{OCH}_{2} \mathrm{C}(\mathrm{O})-\right),(68.07,68.62,68.63,(\mathrm{FcH})), 74.65$ $\left(\mathrm{NHCH}_{2} \mathrm{Fc}\right), 84.93(\mathrm{Fc}), 125.76(\mathrm{ArH}),(132.72$, 145.71, $152.77(\mathrm{Ar})), 169.02(\mathrm{C}=\mathrm{O})$. Microanalysis Calc. for $\mathrm{C}_{96} \mathrm{H}_{108} \mathrm{O}_{8} \mathrm{~N}_{4} \mathrm{Fe}_{4} \cdot 1 / 3\left(\mathrm{CH}_{2} \mathrm{Cl}_{2}\right) \mathrm{C}, 68.16 ; \mathrm{H}$, $6.45 ; \mathrm{N}, 3.30$. Found: C, 68.52; H, 6.53; N, 3.48. FAB MS: $\mathrm{MNa}^{+} @ 1693$. Infared Data (KBr Disc) $1662 \mathrm{~cm}^{-1}$ (carbonyl stretch) m.p. $255^{\circ} \mathrm{C}$.

Synthesis of p-tert-butycalix[4]arenebisferroceneamide (7)

Ferrocenemethylamine $(0.29 \mathrm{~g}, 1.35 \mathrm{mmol})$ and $\mathrm{Et}_{3} \mathrm{~N}(0.14 \mathrm{~g}, 1.38 \mathrm{mmol})$ were dissolved in dry dichloromethane $(25 \mathrm{ml})$ and added to a round bottomed 

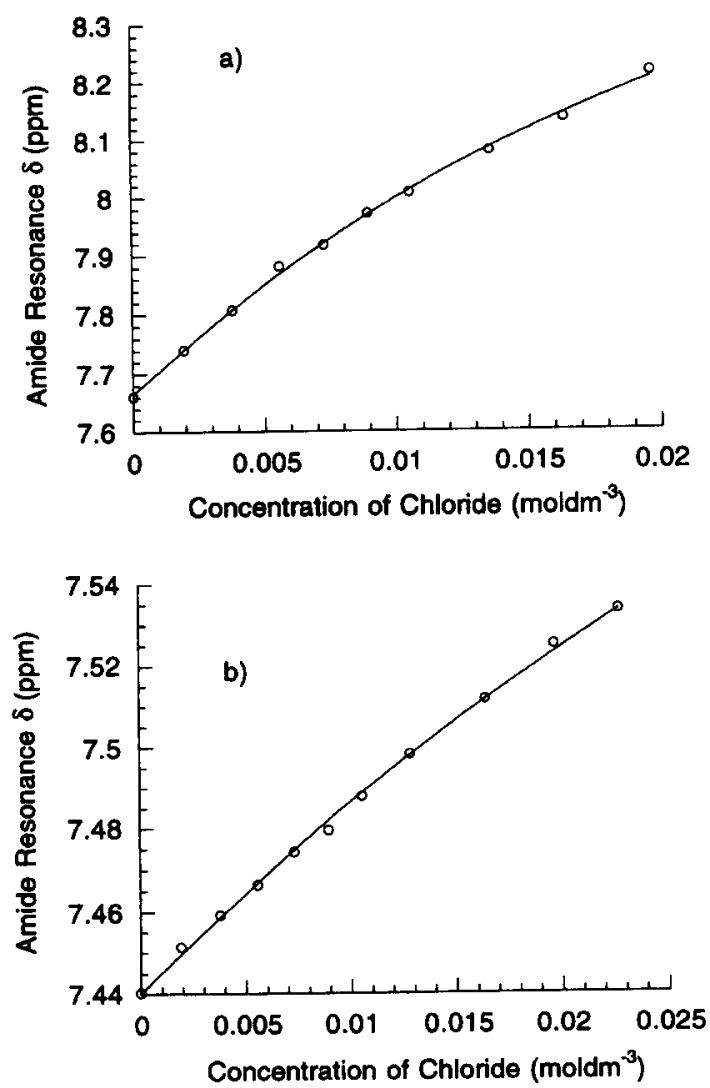

Fig. 3. NMR titrations $\left(\mathrm{CD}_{2} \mathrm{Cl}_{2}\right)$ (a) 6 with $\mathrm{Cl}^{-}$and (b) 8 with $\mathrm{Cl}^{-}$.

Table 2. Stability constants obtained by ${ }^{1} \mathrm{H}$ NMR titrations with chloride in dichloromethane- $d_{2}$ (maximum error $\pm 20 \%$ )

\begin{tabular}{cc}
\hline Ligand & Stability constant $\left(\mathbf{M}^{-1}\right)$ \\
\hline 6 & 55 \\
8 & 15 \\
\hline
\end{tabular}

flask containing p-tert-butylcalix[4]arene bis (acid chloride) $(0.54 \mathrm{mmol})$. The reaction mixture was then left stirring under nitrogen, in the dark, for twenty hours to give a deep red solution. This was washed with water $(4 \times 25 \mathrm{ml})$, and the solvent removed in vacuo to give orange/red crystals. Purification by column chromatography on silica, gradient eluting with dichloromethane/methanol (gradient elution: concentration of methanol from $0 \%$ to $5 \%$ ). The product was collected, reduced in vacuo to give orange/yellow crystals $(0.18 \mathrm{~g}, 29 \%) .{ }^{1} \mathrm{H}$ NMR $\left(\mathrm{CDCl}_{3}, 300 \mathrm{MHz}\right)$ $\delta: 0.95\left(\mathrm{~s}, 18 \mathrm{H},\left(\mathrm{CH}_{3}\right)_{3} \mathrm{C}\right), 1.26\left(\mathrm{~s}, 18 \mathrm{H},\left(\mathrm{CH}_{3}\right)_{3} \mathrm{C}\right)$, $3.27\left(\mathrm{~d},{ }^{2} \mathrm{~J}=13.3 \mathrm{~Hz}, 4 \mathrm{H}, \operatorname{ArCH}_{2} \mathrm{Ar}: \mathrm{H}_{\mathrm{eq}}\right), 3.87$ (d,
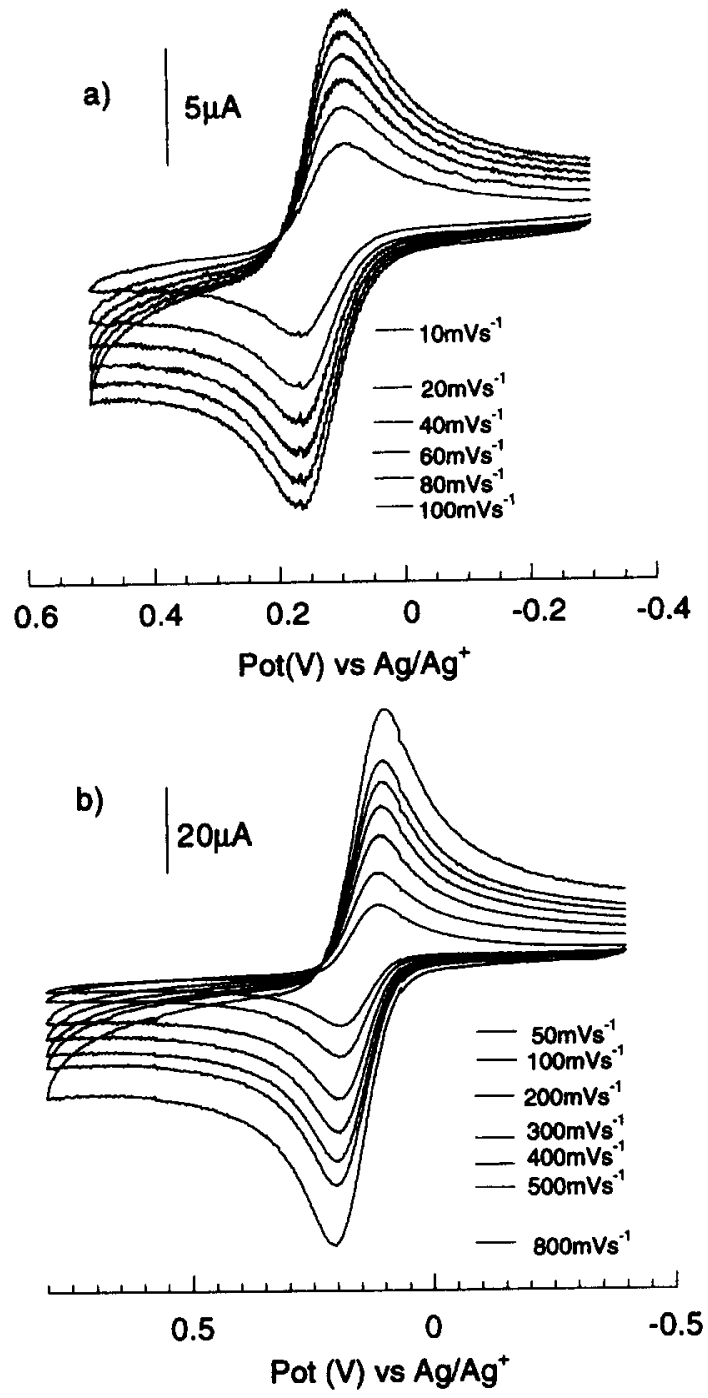

Fig. 4. Quasi-reversible cyclic voltammograms of (a) (6) and (b) (7) recorded at $1.0 \times 10^{-3} \mathrm{~mol} \mathrm{dm}^{-3}$ (ligand). Glassy carbon working electrode, $\mathrm{Ag}^{+} / \mathrm{Ag}$ reference electrode (+330 mV vs S.C.E.). Recorded in $\mathrm{CH}_{2} \mathrm{Cl}_{2} / \mathrm{CH}_{3} \mathrm{CN}$ (35:65 $\mathrm{v} / \mathrm{v})$.

$\left.{ }^{2} \mathrm{~J}=13.3 \mathrm{~Hz}, 4 \mathrm{H}, \mathrm{ArCH} \mathrm{Ar}_{2}: \mathrm{H}_{\mathrm{ax}}\right), 4.10(\mathrm{~s}, 4 \mathrm{H}, \mathrm{FcH})$, $4.13(\mathrm{~m}, 4 \mathrm{H}, \mathrm{FcH}), 4.15(\mathrm{~m}, 4 \mathrm{H}, \mathrm{FcH}), 4.28(\mathrm{~d}, 4 \mathrm{H}$, $\left.\mathrm{NHCH}{ }_{2} \mathrm{Fc}\right), 4.38\left(\mathrm{~s}, 4 \mathrm{H},\left(\mathrm{OCH}_{2} \mathrm{C}(\mathrm{O})\right), 5.31\left(\mathrm{CH}_{2} \mathrm{Cl}_{2}\right)\right.$, $6.78(\mathrm{~s}, 4 \mathrm{H}, \mathrm{ArH}), 6.99(\mathrm{~s}, 4 \mathrm{H}, \mathrm{ArH}), 8.74(\mathrm{t}, 2 \mathrm{H}$, NH). ${ }^{13} \mathrm{C} \mathrm{NMR/DEPT}\left(\mathrm{CDCl}_{3}, 75.42 \mathrm{MHz}\right) \delta: 30.90$ $\left(\left(\mathrm{CH}_{3}\right)_{3} \mathrm{C}\right), 31.83\left(\left(\mathrm{CH}_{3}\right)_{3} \mathrm{C}\right), 31.88\left(\mathrm{ArCH}{ }_{2} \mathrm{Ar}\right), 33.89$ $\left(\left(\mathrm{CH}_{3}\right)_{3} \mathrm{C}\right), 34.20\left(\left(\mathrm{CH}_{3}\right)_{3} \mathrm{C}\right), 39.91\left(\mathrm{OCH}_{2}\right)$, [68.34, 68.89, 69.56 (FcH)], $74.77\left(\mathrm{NHCH}_{2} \mathrm{Fc}\right), 82.47(\mathrm{Fc})$, 125.32 (ArH), 126.00 (ArH), [126.73, 132.10, 142.71, 148.21, 149.23 (Ar)], $167.76(C=\mathrm{O})$. Microanalysis : Calc. for $\mathrm{C}_{70} \mathrm{H}_{82} \mathrm{O}_{6} \mathrm{~N}_{2} \mathrm{Fe}_{2} \cdot 1 / 3\left(\mathrm{CH}_{2} \mathrm{Cl}_{2}\right) \mathrm{C}, 71.14 ; \mathrm{H}$, $7.02 ; \mathrm{N}, 2.36$. Found: C, 71.88; H, 7.18; N, 2.48 . FAB MS: $\mathrm{M}^{+} @ 1158 ; \mathrm{MNa}^{+} @ 1181$. Infared Data (KBr Disk) : $1681 \mathrm{~cm}^{-1}$ (carbonyl stretch). m.p. $245^{\circ} \mathrm{C}$ (dec). 
Table 3. Maximum cathodic shifts in the presence of excess anions

\begin{tabular}{lccc}
\hline & \multicolumn{3}{c}{ Ligand } \\
& \multicolumn{6}{c}{$\mathbf{6}$} & $\mathbf{7}$ & $\mathbf{8}$ \\
\hline $\mathrm{E}_{12} / \mathrm{V}\left(\mathrm{vs} \mathrm{Ag} / \mathrm{Ag}^{+}\right)$ & 0.1242 & 0.1892 & 0.1318 \\
$\Delta(\mathrm{Cl}) / \mathrm{mV}$ & 15 & $<5$ & 20 \\
$\Delta \mathrm{E}\left(\mathrm{HSO}_{4}^{-}\right) / \mathrm{mV}$ & 15 & $<5$ & 20 \\
$\Delta \mathrm{E}\left(\mathrm{H}_{2} \mathrm{PO}_{4}^{-}\right) / \mathrm{mV}$ & 160 & $<5$ & 160 \\
\hline
\end{tabular}

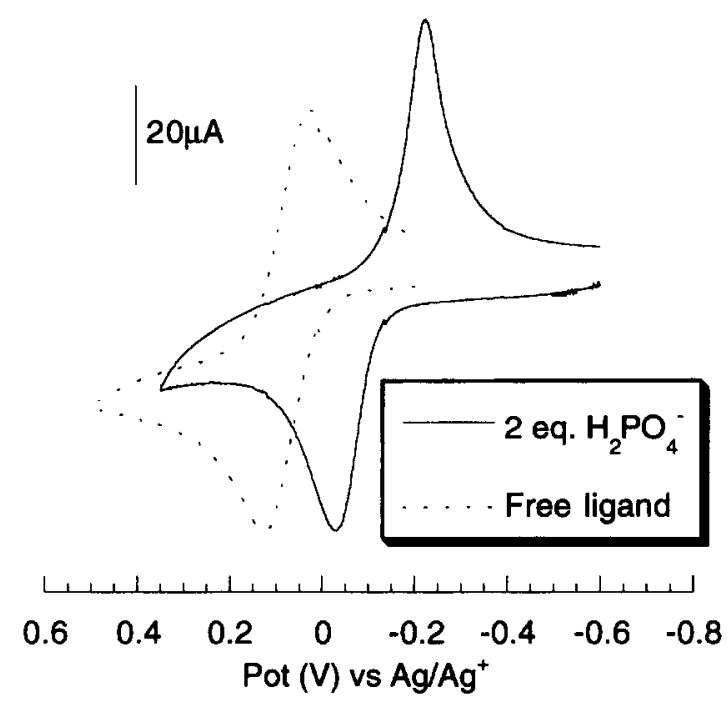

Fig. 5. Cyclic voltammograms of compound 6 in the absence and presence of two equivalents of dihydrogen phosphate in $35 \% \mathrm{CH}_{2} \mathrm{Cl}_{2} / \mathrm{CH}_{3} \mathrm{CN}$. Scan rate $100 \mathrm{mV} \mathrm{s}^{-1}$, glassy carbon working electrode, $\mathrm{Ag}^{+} / \mathrm{Ag}$ reference electrode $(+330 \mathrm{mV}$ vs S.C.E.). Recorded in $\mathrm{CH}_{2} \mathrm{Cl}_{2} / \mathrm{CH}_{3} \mathrm{CN}(35: 65 \mathrm{v} / \mathrm{v})$.

Synthesis of p-tert-butylcalix[5]arenepentaferroceneamide $(\mathbf{8})$

Ferrocenemethylamine $(0.60 \mathrm{~g}, 2.79 \mathrm{mmol})$, triethylamine $(0.28 \mathrm{~g}, 2.77 \mathrm{mmol})$ and p-tert-butycalix[5]arene penta (acid chloride) (4.7 mmol) were dissolved in dry dichloromethane $(30 \mathrm{ml})$ and the reaction mixture stirred for eighteen hours. After washing with water, the product was dried over magnesium sulfate and the solvent removed under reduced pressure to give brown/orange crystals. These were purified by column chromatography on silica gel, gradient eluting with dichloromethane/methanol. The product was collected, reduced in vacuo, and then precipitated as a yellow powder $(0.16 \mathrm{~g}, 16 \%)$ from a dichloromethane/methanol mixture (gradient elution: concentration of methanol from $0 \%$ to $5 \%$ ). ${ }^{1} \mathrm{H}$ NMR $\left(\mathrm{CDCl}_{3}, 300 \mathrm{MHz}\right) \delta: 1.02\left(\mathrm{~s}, 45 \mathrm{H},\left(\mathrm{CH}_{3}\right)_{3} \mathrm{C}\right), 3.31$ $\left(\mathrm{d}, 5 \mathrm{H}, \mathrm{J}=14.0 \mathrm{~Hz}, \operatorname{ArCH}_{2} \mathrm{Ar}: \mathrm{H}_{\mathrm{eq}}\right), 4.12(\mathrm{~s}, 10 \mathrm{H}$, $\left.\mathrm{OCH}_{2}\right), 4.17(\mathrm{~s}, 25 \mathrm{H}, \mathrm{FcH}), 4.24(\mathrm{~m}, 10 \mathrm{H}, \mathrm{FcH}), 4.26$ (m, 10H, $\mathrm{FcH}$ ), 4.27 (d, 10H, $-\mathrm{NHCH}_{2}$ ), 4.47 (d, $\left.5 \mathrm{H}, \mathrm{J}=14.0 \mathrm{~Hz}, \mathrm{ArCH}_{2} \mathrm{Ar}: \mathrm{H}_{\mathrm{ax}}\right), 6.88(\mathrm{~s}, 10 \mathrm{H}, \mathrm{ArH})$, $7.42(\mathrm{t}, 5 \mathrm{H}, \mathrm{NH}) .{ }^{13} \mathrm{C}$ NMR $\left(\mathrm{CDCl}_{3}, 75.42 \mathrm{MHz}\right) \delta$ : $30.02\left(\mathrm{ArCH} \mathrm{H}_{2} \mathrm{Ar}\right), 31.30\left(\left(\mathrm{CH}_{3}\right)_{3} \mathrm{C}\right), 34.05\left(\left(\mathrm{CH}_{3}\right)_{3} \mathrm{C}\right)$, $38.83\left(\mathrm{OCH}_{2} \mathrm{CO}\right),[68.14,68.59,68.73(\mathrm{FcH})], 72.93$ $\left(\mathrm{NHCH}_{2}\right), 84.93(\mathrm{Fc}),[126.35,132.62,146.11,151.15$ (Ar)], $169.01 \quad(C=0)$. Microanalysis: calc. for $\mathrm{C}_{120} \mathrm{H}_{135} \mathrm{O}_{10} \mathrm{~N}_{5} \mathrm{Fe}_{5}: \mathrm{C}, 69.07 ; \mathrm{H}, 6.52 ; \mathrm{N}, 3.36$ Found : $\mathrm{C}, 69.41 ; \mathrm{H}, 6.75 ; \mathrm{N}, 3.33$. FAB MS: $\mathrm{MH}^{+}$(2) 2087 . $\mathrm{MNa}^{+} \propto 2109$. Infared Data (KBr Disk): $1672 \mathrm{~cm}^{-1}$ (carbonyl stretch). m.p. $295^{\circ} \mathrm{C}$ (dec).

\section{Crystallography}

Single crystal X-ray analysis of 7 was conducted using MoK $\alpha$ radiation with the MARresearch Image Plate System. The crystal was positioned at $75 \mathrm{~mm}$ from the X-ray source. 90 frames were measured at 2 intervals with a counting time of 2 mins. Data analysis was carried out with the XDS program [22]. The structure was solved using direct methods with the Shelx 86 program [23]. Apart from the substituted calixarene, there were several solvent molecules and two methanol and one dichloromethane molecules were located, though there were indications of other disordered solvent molecules. The non-hydrogen atoms were refined with anisotropic thermal parameters apart from the carbon and oxygen atoms in the solvent. All hydrogen atoms were included in calculated positions apart from those in the solvent molecules. The structure was then refined using Shelx [24], $\mathrm{R}$-factors are given in Table 1. All calculations were carried out on a Silicon Graphics R4000 Workstation at the University of Reading.

Acknowledgements - We thank the EPSRC for a studentship (PAG) and the EPSRC together with the University of Reading for the provision of the image plate diffractometer.

\section{REFERENCES}

1. Stryer, L., Biochemistry, 4 th edn ed. W. H. Freeman and Co., New York, 1988.

2. Chakrabarti, P., J. Mol. Biol., 1993, 234, 463-482.

3. Moss, B., Chem. and Ind., 1996, 407.

4. Glidewell, C., Chem. Br., 1990, 26, No. 2, 137.

5. Gale, P. A., Sessler, J. L., Král, V. and Lynch, V., J. Am. Chem. Soc., 1996, 118, 5140.

6. Gale, P. A., Sessler, J. L., Allen, W. E., Tvermoes, N. A. and Lynch, V., Chem. Commun., 1997, 665.

7. Beer, P. D., Chem. Commun., 1996, 689.

8. Sessler, J. L., Cyr, M. J., Lynch, V., McGhee, E. and Ibers, J. A., J. Am. Chem. Soc., 1990, 112, 2810.

9. Sessler, J. L., Cyr, M., Furuta, H., Král, V., Mody, T., Morishima, T., Shionoya, M. and Weghorn, S. J., Pure and Appl. Chem., 1993, 65. 393.

10. Beer, P. D., Hesek, D., Hodacova, J. and Stokes, S. E., J. Chem. Soc. Chem. Commun., 1992, 270.

11. Beer, P. D., Hazlewood, C., Hesek, D., Hoda- 
cova, J. and Stokes, S. E., J. Chem. Soc. Dalton Trans., 1993, 1327.

12. Beer, P. D., Drew, M. G. B., Hazlewood, C., Hesek, D. and Stokes, S. E., J. Chem. Soc. Chem. Commun., 1993, 229.

13. Beer, P. D., Drew, M. G. B., Hazlewood, C., Hesek, D., Hodacova, J. and Stokes, S. E., J. Chem. Soc. Chem. Commun., 1993, 229.

14. Pascal, R. A., Spergel, J. and van Engen, D. V., Tetrahedron Lett., 1986, 27, 4099.

15. Valiyaveettil, S., Engbersen, J. F. J., Verboom, W. and Reinhoudt, D. N., Angew. Chem. Int. Ed. Engl., 1993, 32, 900 .

16. Beer, P. D., Chen, Z., Goulden, A. J., Graydon, A., Stokes, S. E. and Wear, T., J. Chem. Soc. Chem. Commun., 1993, 1834.

17. McKervey, M. A., Seward, E. M., Ferguson, G.,
Ruhl, B. and Harris, S. J., J. Chem. Soc. Chem. Commun., 1985, 388.

18. Arnaud-Neu, F., Schwing-Weill, M. J., Ziat, K., Cremin, S., Harris, S. J. and McKervey, M. A., New. J. Chem., 1991, 15, 33.

19. Spencer, P., Polyaza redox-active acyclic and macrocyclic compounds designed to bind cations and anions, D.Phil. thesis, University of Oxford, 1994.

20. Hynes, M. J., J. Chem. Soc., Dalton Trans., 1993, 311.

21. Instrumental Methods in Electrochemistry, Southampton Electrochemistry Group, Ellis Horwood Limited, University of Southampton, 1990.

22. Kabsch, W., J. Appl. Cryst., 1988, 21, 916.

23. Sheldrick, G. M., Acta Cryst., 1990, A46, 467.

24. Sheldrick, G. M., Pers. comm., 1993. 